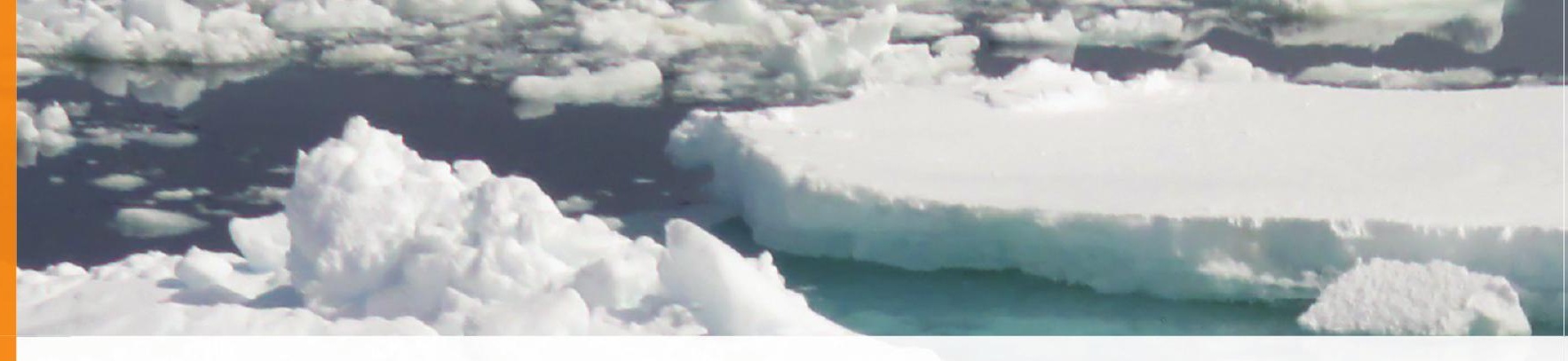

\title{
IMPACT ASSESSMENT OF SEWAGE OF BRAZILIAN ANTARCTIC STATION ON THE PLASMA CONSTITUENTS OF ANTARCTIC FISH Notothenia rossii
} http://dx.doi.org/10.4322/apa.2014.108

\author{
Edson Rodrigues Júnior ${ }^{3, *}$, Mariana Feijó-Oliveira ${ }^{3}$, Gannabathula Sree Vani, \\ Cecília Nahomi Kawagoe Suda1', Lucélia Donatti ${ }^{3}$, Cíntia Machado ${ }^{3}$, \\ Helena Passeri Lavrado², Edson Rodrigues ${ }^{1}$
}

\author{
'Instituto Básico de Biociências, Universidade de Taubaté, Av. Tiradentes 500, Centro, Taubaté, CEP 12030-180, SP, Brazil \\ ${ }^{2}$ Departamento de Biologia Celular, Centro Politécnico s/nº, Universidade Federal do Paraná, \\ Jd das Américas, CEP 81990-970, Curitiba, PR, Brazil \\ ${ }^{3}$ Departamento de Biologia Marinha, Universidade Federal do Rio de Janeiro, Av. Carlos Chagas Filho 373 \\ Ilha do Fundão, CEP 21941-902, Rio de Janeiro, RJ, Brazil
}

*e-mail: edsonrodj@gmail.com

\begin{abstract}
The burning of fossil fuels, sewage dumping and leakage of combustible oil has been polluting Antarctica around the scientific stations and ship anchoring locations. The present work evaluated the effect of sewage effluent of Antarctic Station Commandant Ferraz (EACF) on the plasmatic levels of glucose, triglycerides, cholesterol, total proteins, albumin and globulins of Antarctic fish Notothenia rossii. The bioassays were conducted with effluent from the sewage processing station of EACF diluted in seawater. In the presence of sewage, glucose, triglycerides, total proteins and globulins reduced in the plasma of N. rossii, where as albumin and cholesterol increased. In this case, the reduction of energy metabolites (glucose and triglycerides) plasmatic levels can be related with the rise in energy demand of $N$. rossii induced by the sewage.
\end{abstract}

Keywords: Antarctica, Fish Metabolism, Biochemical Marker, Notothenia rossii

\section{Introduction}

Antarctica was rapidly explored and occupied as soon as it was discovered in the XIX century. In 1959, the Antarctic treaty was officially signed and set forth the rights and duties of all those who occupy this continent. The formal commitment for the preservation and monitoring of Antarctica as a natural reserve restricting the continent to peace and science was explicitly stated in the Environmental protection protocol (Madrid Protocol) and signed by the parties to the Antarctic Treaty of 1991(Roura \& Hemmings, 2011).

The scientific occupation introduced pollutants that were not originally present in Antarctica. The burning of fossil fuels, effluents from the scientific stations/ships and the leakage of combustible oil has contaminated the coastal regions with human sewage, heavy metals and persistent organic pollutants (Tin et al., 2009; Aronson et al., 2011). The global climatic changes and localized pollution around the scientific stations has raised concerns about its impact on the Antarctic ecosystems (Aronson et al., 2011).

The present study aims to evaluate the chronic effect of sewage effluents of the EACF on the plasmatic constituent's levels of the Antarctic fish Notothenia rossii.

\section{Materials and Methods}

Specimens of N. rossii were captured at Punta Plaza, Keller Peninsula, Admiralty Bay, King George Island, Antarctica, from January to March 2011, at depths of 10 to $20 \mathrm{~m}$ using fishing line. The fishes were transferred to aquariums at EACF and after 48 hours, anesthetized, measured, weighed, marked and sorted for bioassay. The effluent from the sewage processing station (SPS) of EACF was fed slowly into the tanks for final concentrations of $0.05 \%(\mathrm{v} / \mathrm{v})$ and $0.5 \%$ (v/v), with 10 fish for each experiment. The experimental 
controls (EC) were 10 fish kept at thermo-saline conditions of 0-35, without effluents from SPS. The fishes were kept in the experimental condition for 25 days. Every two days the fish were fed with Antarctic fish muscle, corresponding to $1 \%$ of the body mass. The blood of the nature control group (NC) fish was collected as soon as the $N$. rossii were removed from the water to minimize the possible effect of stress arising from the capture.

The blood of the fish was obtained by caudal vein puncture with a heparinized syringe. The sample was centrifuged for $5 \mathrm{~min}$ at $2000 \mathrm{rpm}$, the plasma was transferred to cryogenic tubes and frozen in liquid nitrogen. The plasma levels of glucose, triglycerides, cholesterol, total proteins and albumin were determined by spectrophotometric methods adapted for micro volumes using reagent kits from LabTest Diagnostica S/A. The statistical comparison of the control and experimental groups was done using one way ANOVA followed by a Tukey multiple comparison post tests. The differences were considered significant for $p<0.05$ (Motulsky, 1995).

\section{Results}

The effect of sewage on the levels of glucose, triglycerides and cholesterol are shown in figure 1. The total proteins
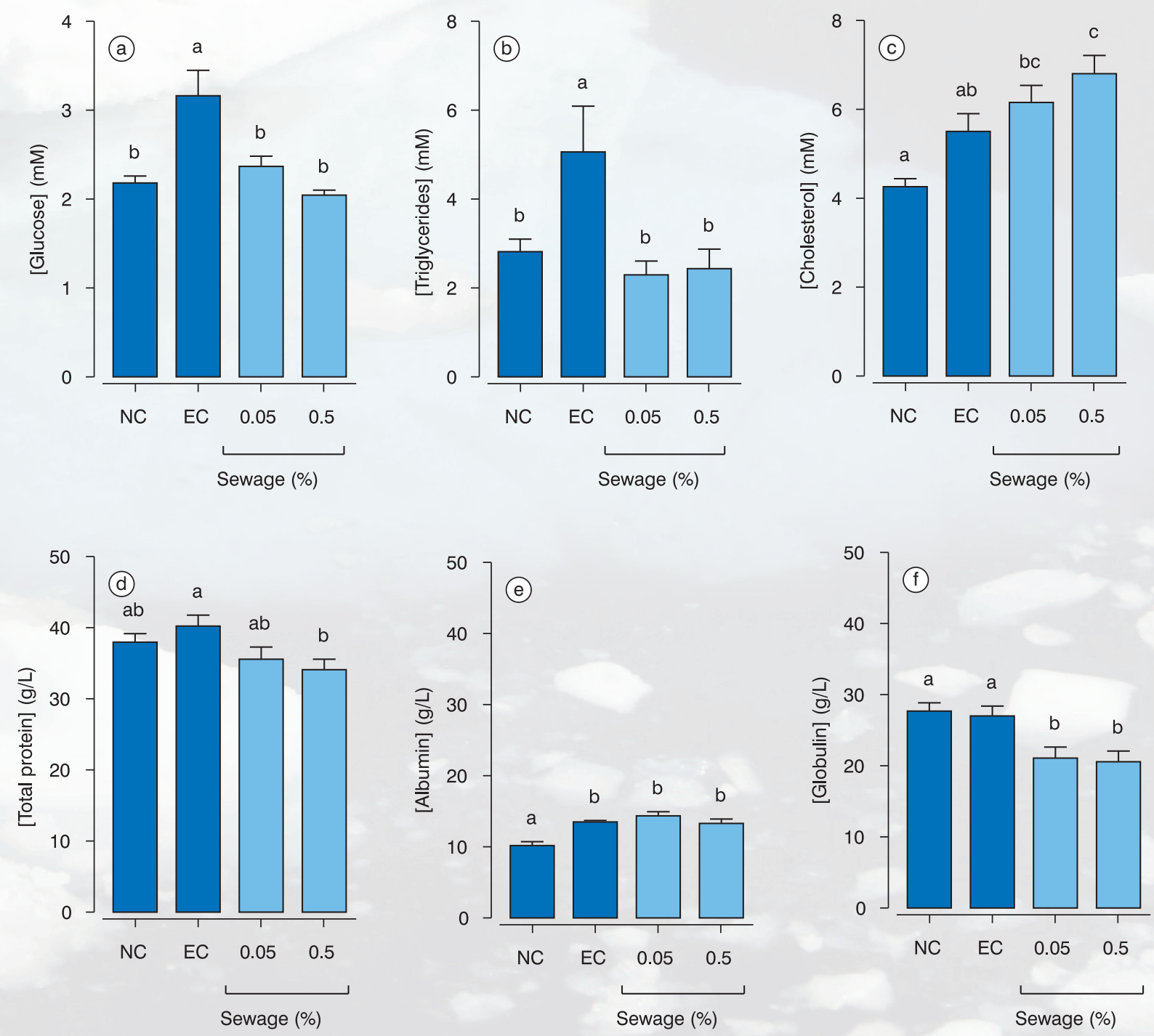

Figure 1. Levels of glucose (a), triglycerides (b) and cholesterol (c), proteins (d), albumin (e) and globulins (f) in the plasma of N. rossii. Different letters above the bars indicate significant difference $(p<0,05)$ between nature control $(\mathrm{NC})$, experimental control $(\mathrm{EC})$ and sewage groups. 


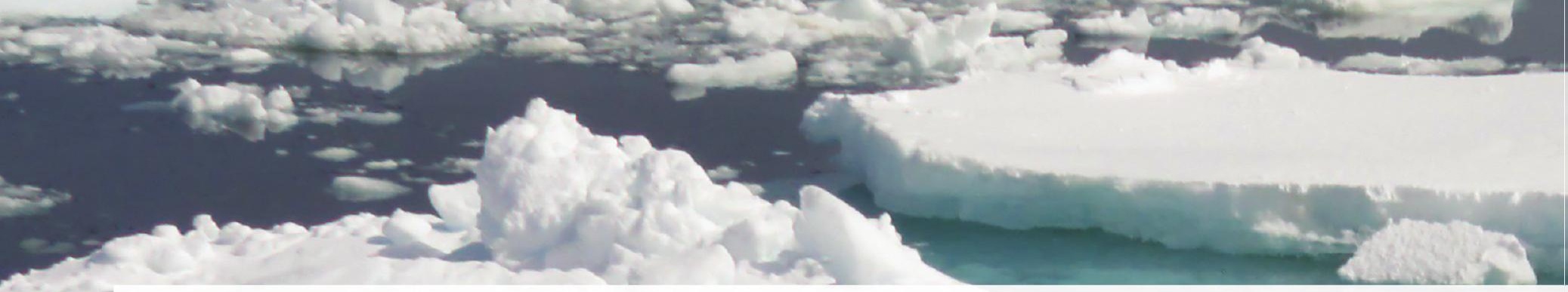

reduction (Figure 1d) observed in the sewage groups was due to reduction in the globulin levels (Figure 1f) and were followed by a rise in the albumin fraction (Figure 1e).

\section{Discussion}

The glucose levels in both the sewage groups were less than the experimental control. The difference of the glucose levels in the nature and experimental control indicates that confinement stress results in hyperglycemia (Figure 1a). The difference in glycaemia between the two experimental groups with SPS effluents was not significant. The increase in glucose in vertebrates has been associated with the energy demands of "fight-or-flight" reaction (Pottinger et al., 2000). The reduction in plasma glucose levels of $N$. rossii in experimental conditions with sewage could be due to increased energy demands. The same profile of glucose was observed for triglycerides (Figure 1b). The presence of ample and diffuse adipose tissue, as well as elevated oxidative potential of liver muscle and heart in the Antarctic fish, supports the view of metabolism based on lipids (Crockett \& Sidell, 1990; Sidell et al., 1995). The lipid plasmatic transport in the fish is similar to mammals, the very low density lipoprotein (VLDL) being the main transporter of TG, whereas low density lipoprotein (LDL) and high density lipoprotein (HDL) are rich in cholesterol. In fish, the low levels or absence of albumin is compensated by fatty acid transport through HDL (Metcalf et al., 1999; Nanton et al., 2006). The relatively high levels of cholesterol in the plasma of experimental control and sewage, compared to the nature control (Figure 1c), could be related with the rise in the energy demands and the plasmatic transport of fatty acids through HDLs. So, the tendency of cholesterol levels to rise as a function of sewage concentration could be related with to the possible increase in energy demand. The albumin levels in the vertebrates has been associated with fatty acid, divalent metallic cations transport and blood colloidosmotic pressure (Metcalf et al., 1998). Therefore, the elevation in the albumin levels and reduction in the globulins of $N$. rossii plasma were impacted by experimental confinement and the sewage.

\section{Conclusion}

The confinement was capable of inducing rise of glucose, triglycerides (not significant) and cholesterol in plasma of $N$. rossii. In the presence of sewage, the glucose and triglycerides levels suffered reduction, signaling possible rise in energy demand. The elevation of cholesterol levels in the presence of sewage could be related to the lipid relocation with energetic aims. The alterations observed in the presence of sewage were not proportional to the concentration of this effluent. Plasmatic cholesterol and globulins emerge as potential biomarkers of the sewage pollution.

\section{Acknowledgements}

This study was sponsored by the Brazilian National Institute of Science and Technology - Antarctic Environmental Research (INCT-APA, Portuguese acronym), and with the National Council for Scientific and Technological Development, (CNPq, Portuguese acronym) process n ${ }^{\circ} 574018 / 2008-5$ and the Ministry of Environment (MMA, Portuguese acronym), the Ministry of Science and Technology (MCT, Portuguese acronym) and the Secretariat of the Interministerial Commission for Resources of the Sea (SECIRM, Portuguese acronym).

\section{References}

Aronson, R.B.; Thatje, S.; McClintock, J.B. \& Hughes, K.A. (2011). Anthropogenic impacts on marine ecosystems in Antarctica. 1223: 82-107p

Crockett, A.B. \& Sidell, B.D. (1990). Some pathways of energy metabolism are cold adapted in Antarctic fishes. Physiological Zoology, 63: 472-488

Metcalf, V.; Brennan, S.; Chambers, G. \& George, P. (1998). The Albumins of Chinook Salmon (Oncorhynchus tshawytscha) and Brown Trout (Salmo trutta) Appear to Lack a Propeptide. Archives of Biochemistry and Biophysics, 350(2): $239-244$. 
Metcalf, V.J.; Brennan, S.O.; Chambers, G. \& George, P.M. (1999). High density lipoprotein (HDL), and not albumin, is the major palmitate binding protein in New Zealand long-finned (Anguilla dieffenbachii) and short-finned eel (Anguilla australis schmidtii) plasma. Biochimica et Biophysica Acta, 1429(2): 467-475.

Motulsky, H. (1995). Intuitive Biostatistics. ed. New York. Oxford University Press.

Nanton, D.A.; McNiven, M.A. \& Lall, S.P. (2006). Serum lipoproteins in haddock, Melanogrammus aeglefinus L. Aquaculture Nutrition, 12(5): 363-371.

Pottinger, T.G.; Carrick, T.R.; Appleby, A. \& Yeomans, W.E. (2000). High blood cortisol levels and low cortisol receptor affinity: Is the chub, Leuciscus cephalus, a cortisol-resistant teleost? General and Comparative Endocrinology, 120(1): 108-117.

Roura, R.M. \& Hemmings, A.D. (2011). Realising strategic environmental assessment in antarctica. Journal of Environmental Assessment Policy and Management. 13(3): 483-514.

Sidell, B.D.; Crockett, E.L. \& Driedzic, W.R. (1995). Antarctic fish tissues preferentially catabolize monoenoic fatty acids. Journal of Experimental Zoology, 271(2): 73-81.

Tin, T.; Fleming, Z.L.; Hughes, K.A.; Ainley, D.G.; Convey, P.; Moreno, C.A.; Pfeiffer, S.; Scott, J. \& Snape, I. (2009). Impacts of local human activities on the Antarctic environment. Antarctic Science, 21(1): 3-33. 